Journal

of Geography

Politics and Society

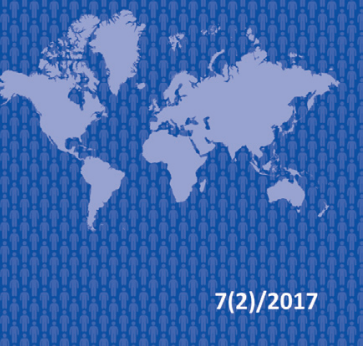

\section{Journal of Geography, Politics and Society}

2017, 7(2), 98-107

DOI 10.4467/24512249JG.17.018.6634

\title{
INTEGRAL ASSESSMENT OF ECONOMIC SECURITY OF A BORDERLAND REGION (THE CASE OF LVIV OBLAST)
}

\author{
Myroslava Knysh (1), Anna Smaliychuk (2) \\ (1) Chair of Economic and Social Geography, Faculty of Geography, Ivan Franko National University of Lviv, Doroshenka 41, 79000 Lviv, Ukraine, \\ e-mail: m.knysh@gmail.com (corresponding author) \\ (2) Chair of Economic and Social Geography, Faculty of Geography, Ivan Franko National University of Lviv, Doroshenka 41, 79000 Lviv, Ukraine, \\ e-mail: anakonechna87@gmail.com
}

\section{Citation}

Knysh M., Smaliychuk A., 2017, Integral assessment of economic security of a borderland region (the case of Lviv Oblast), Journal of Geography, Politics and Society, 7(2), 98-107.

\begin{abstract}
In the article, criteria and indicators of economic security assessment of administrative and territorial units of a region are suggested. Component and integral spatial-temporal assessment of economic security of the Lviv Oblast is carried out using principal component analysis. Future scenarios of ES of the Lviv Oblast are suggested based on results of SWOT analysis.
\end{abstract}

\section{Key words}

Economic security, Lviv Oblast, criteria, indicators, components of economic security, integral economic security, scenarios.

\section{Introduction}

In the context of globalization and market economy, risks of economic activity, economic vulnerability and interdependence of regions at all levels, what in Ukraine is accompanied by long transformation in economy, are increasing. Considering this, safety studies in various areas of public life, including economy, are particularly relevant. Economic security (ES) as an important component of national security is in the focus of scientists at various levels - from global to local. However, in scientific literature, it is usually examined at the state level that makes it impossible to consider the effectiveness of using of local resources of regions and their impact on the ES of spatial entities of higher taxonomic ranks.
A significant contribution to the study of various aspects of national and regional ES has been done by Ukrainian scientists (Шлемко, Бінько, 1997; Геєць, 1999; Мунтіян, 1999; Пастернак-Таранушенко, 2002; Пономаренко, Клебанова, Чернова, 2004; Герасимчук, 2006; Новікова, Покотиленко, 2006; Сухоруков, 2009; Варналій, 2011).

The issue of economic security in Ukrainian studies was considered in the late twentieth century; it was developed mainly by economic scientists, but the concept of "economic security" is extremely broad, and its definition is yet not fully formed ( $\mathrm{Ha}-$ конечна, 2010), several approaches to definition of the term can be found:

1. Ability of economy to resist or prevent threats.

2. Protection condition of interests at all levels. 


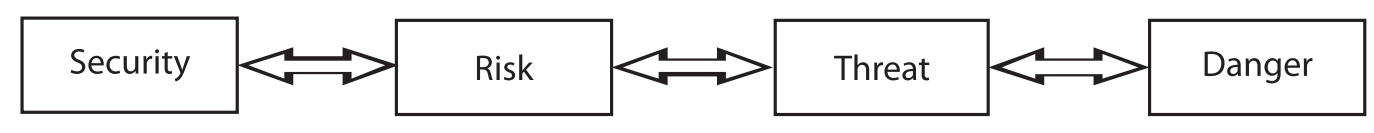

Fig. 1. Qualitative assessment of transition of security-danger condition

Source: Own studies based on Наконечна, 2011; Герасимчук, 2006.

3. Level of availability and effective use of resources.

4. Economy condition that ensures sovereignty, independence and sustainable development.

5. Integral - as integration or a combination of the above four approaches.

Social and geographical aspects of economic security studies which are largely ignored by scientists are manifested through: 1) factors of internal and external environment that influence formation of $E S$; 2) geospatial organization of ES in general and its individual components in particular; 3 ) spatial approach in the course of development of measures to guarantee ES. Considering advantages and disadvantages of these approaches and taking into account social and geographic aspects of our research, it is suggested to treat "economic security of a region" as a geospatial organization of economy of a region as a whole and its individual components in particular, which is formed under the influence of favorable factors and allows keeping sustainable development able to meet the economic needs of a region in the context of national interests (Наконечна, 2010).

\section{Criteria and indicators of economic security of an oblast level}

Level of ES is manifested through a system of criteria that are considered as classification attributes of its qualitative and quantitative assessment. The criteria allow analyzing both retrospective and current state of economic security of an administrative-territorial unit, and also making forecasting with the use of mathematical methods. Qualitative assessment is detected in ES conditions - danger, threat, risk, security, and quantitative - in the setting of threshold of its being in a particular condition (Fig. 1). For qualitative assessment, a system of indicators is selected and threshold values of ES are set, violation of which causes adverse trends (Наконечна, 2011).

In the process of research of geospatial organization of an oblast region ES (in terms of administrative-territorial units - raions (districts) and cities of oblast importance), arises the problem of adequate replacement of important, or even basic indicators (such as gross regional product), which are independent parameters and are the basis for determining of relative indexes at national and regional levels. In this regard, the following principles of selection of ES indicators are proposed:

1. Principle of hierarchy - correspondence of statistic data to the level of economic research.

2. Principle of universality - presence of indexes at all levels of research.

3. Principle of adequacy - replacement of indexes of higher level with indexes of lower level.

4. Principle of temporal consistency - values of indexes should be selected during the same time period.

Tab. 1. Indicators of measurement of economic security of region administrative-territorial units

\begin{tabular}{|c|c|c|c|}
\hline $\begin{array}{c}\text { ES } \\
\text { com- } \\
\text { ponent }\end{array}$ & Indicators & $\begin{array}{c}\text { ES } \\
\text { com- } \\
\text { ponent }\end{array}$ & Indicators \\
\hline \multirow{6}{*}{$\overline{\frac{\pi}{u}}$} & $\begin{array}{l}\text { Expenditures of local budgets for social security, } \\
\text { UAH. per person }\end{array}$ & \multirow{6}{*}{ 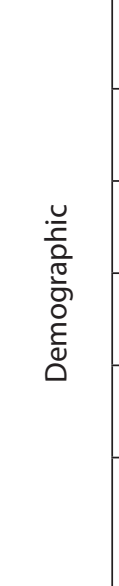 } & Fertility rate, \%o \\
\hline & $\begin{array}{l}\text { Expenditures of local budgets for education, UAH. } \\
\text { per person }\end{array}$ & & Mortality rate, \%o \\
\hline & $\begin{array}{l}\text { Expenditures of local budgets for healthcare, UAH. } \\
\text { per person }\end{array}$ & & Child mortality rate, persons per 1000 of live born \\
\hline & $\begin{array}{l}\text { Availability of hospital beds for population, per } 10 \\
\text { thousand of population }\end{array}$ & & Balance of intra-regional migration \\
\hline & $\begin{array}{l}\text { Availability of doctors for population, per } 10 \text { thou- } \\
\text { sand of population }\end{array}$ & & Balance of external migration \\
\hline & $\begin{array}{l}\text { The number of patients with first time established } \\
\text { diagnosis of alcoholic psychosis, per } 100 \text { thousand } \\
\text { of population }\end{array}$ & & $\begin{array}{l}\text { The total fertility rate (average number of children } \\
\text { born to a woman over lifetime), persons }\end{array}$ \\
\hline
\end{tabular}




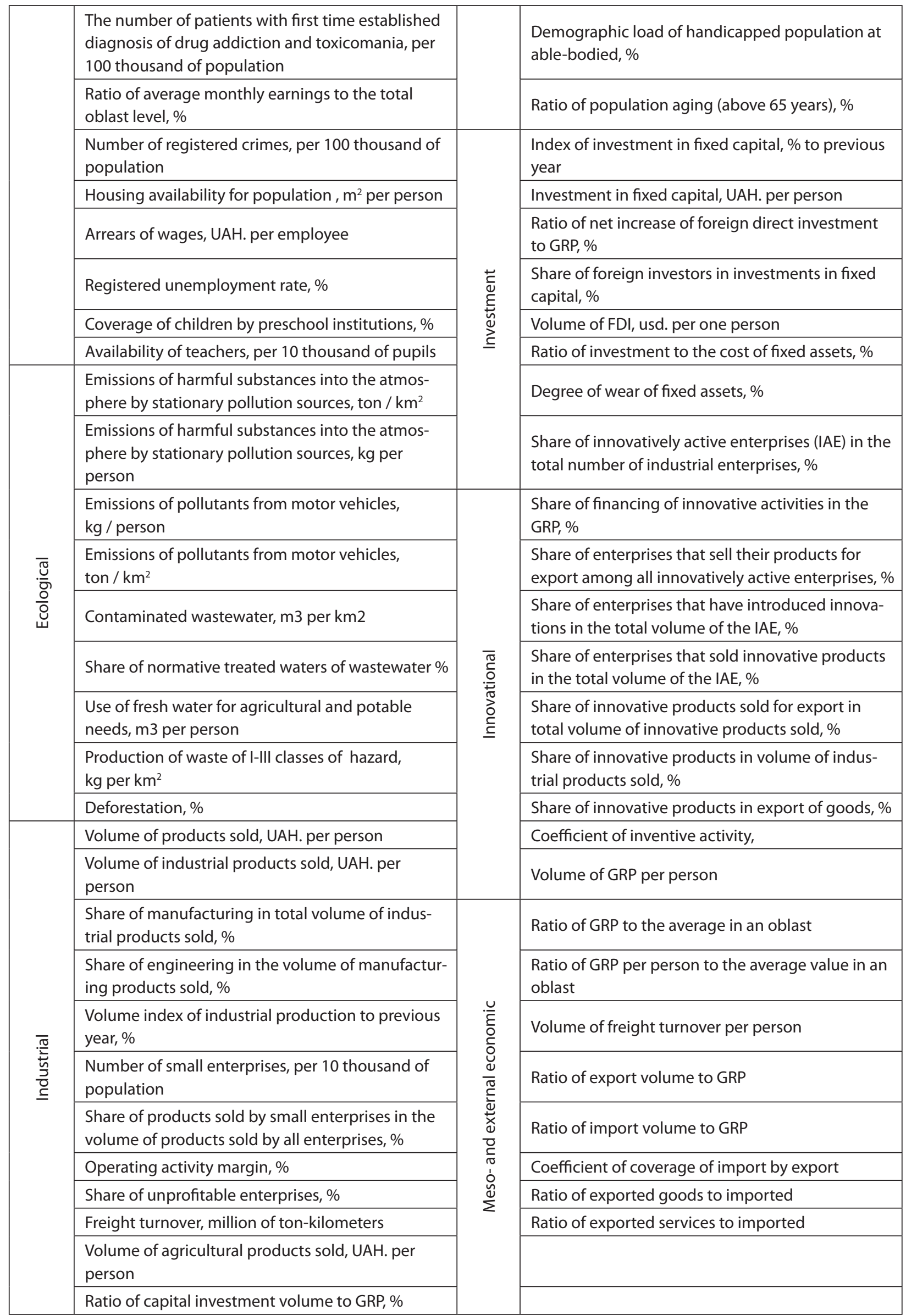

Source: Selected by the authors according to the Main Statistical Office in Lviv region (oblast) on Архів видань 2005, 2010, 2015; База даних. 
5. Principle of spatial consistency - values of indexes should be selected in terms of administrative territorial units of the same level.

For the research of ES at the oblast level, indicators (Tab. 1) that most fully characterize current and dynamic condition of ES in general and its components. in particular. Indicators are selected from regional statistics database, taking into account the principle of correspondence of research scope.

Each of the defined components of ES has approximately the same (8-10) quantitative set of indicators except social. This is because social component describes and covers volume range of indicators and quality of life indexes. Overall, we selected 68 indicators, 19 of which are indicators-distimulators, growth of indexes of which is primarily the source of threats to ES of a region.

\section{Spatial-temporal analysis of components of economic security of Lviv Oblast}

Taking into account the lack of ES study at regional level, an approach to its structuring in the case of transition from national level to the level of oblast region is suggested. We offer to distinguish the following components as components of economic security of administrative raions and cities of oblast importance: demographic, social, ecological, industrial, investment, innovational, meso- and external economic.
In our study we used principal component analysis (PCA) to calculate indexes of each component of ES employing Statistica software with further spatial-temporal analysis of the results. Indicators of each component are combined in the main factors and the extent of their impact on the level of economic security in each administrative-territorial unit of the region is defined. Qualitative assessment of the received component indexes of ES within the region showed that meso- and external economic is in the condition of danger, three - in the condition of threat, three - demographic, ecological and social - in the condition of risk (Fig. 2).

Components of economic security in the condition of risk are demographic, social, and ecological. Demographic security (DS) is characterized by large territorial differentiation of the correspondent index, which ranges from 0.201 in Peremyshliany raion to 0.689 in Yavoriv raion. The rest of the administrativeterritorial units of the Lviv Obast are in the condition of risk and threat. We revealed that the indicators of child mortality and coefficient of natural population growth most negatively affect the demographic security of administrative-territorial units of the Lviv Oblast. During the investigated period, the index of demographic security in the oblast had a slight positive trend.

According to the indexes of social security (SS), 22 of administrative-territorial units of the Lviv Oblast are in the condition of risk, seven - in the condition of threat. The absolute values of the index in the

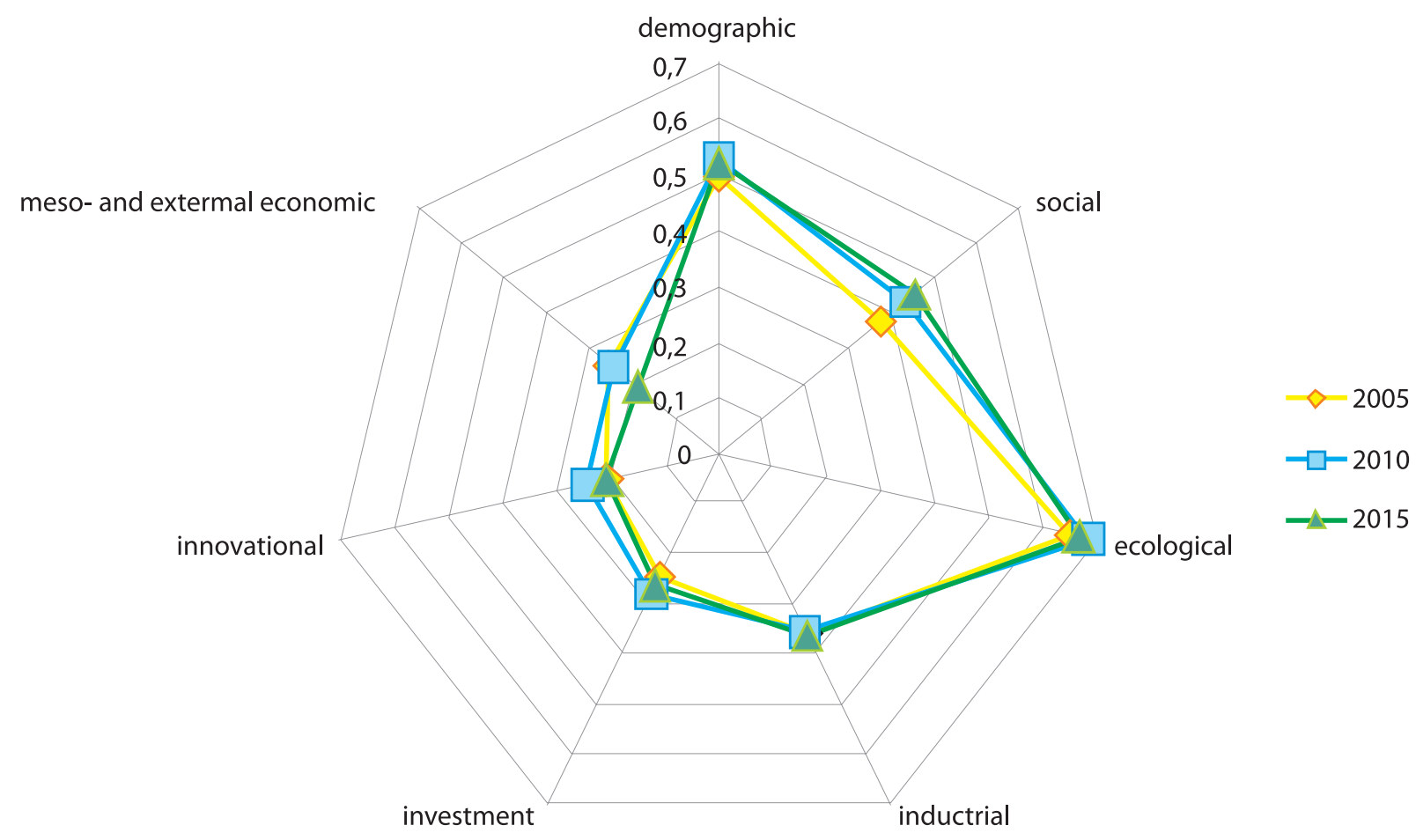

Fig. 2. Dynamics of components of economic security of Lviv Oblast

Source: Own calculation. 
region vary from 0.326 in the city of Chervonohrad to 0.647 in the city of Morshyn. Influence of different indicators on the formation of the index of SS in different types of administrative-territorial units is different, but generally in the region, low values of the indicators of social problems positively influence it. Over the period of 2005-2015 in most administrative-territorial units, the indices of social security had been increasing.
The ecological component has the highest index among all the components of economic security. For seventeen raions of the Lviv Oblast, the condition of security of this component is revealed, for ten more administrative-territorial units - the condition of risk, and Chervonohrad, Lviv and Stryi, taking into account concentration of sources of environmental pollution, are in the condition of threat.

Industrial, investment, innovational and mesoand external economic components are in the

Tab. 2. Componential and integral assessments of economic security of Lviv Oblast in 2015

\begin{tabular}{|c|c|c|c|c|c|c|c|c|c|}
\hline \multirow[b]{2}{*}{ 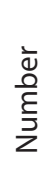 } & \multirow{2}{*}{$\begin{array}{l}\text { Administrative } \\
\text { raions } \\
\text { and cities of oblast } \\
\text { importance }\end{array}$} & \multicolumn{7}{|c|}{ Indexes of components of economic security } & \multirow{2}{*}{$\begin{array}{l}\text { Integral } \\
\text { index of } \\
\text { economic } \\
\text { security }\end{array}$} \\
\hline & & $\begin{array}{l}\text { demo- } \\
\text { graphic }\end{array}$ & social & ecological & industrial & $\begin{array}{l}\text { invest- } \\
\text { ment }\end{array}$ & $\begin{array}{c}\text { innova- } \\
\text { tional }\end{array}$ & $\begin{array}{l}\text { meso- and } \\
\text { external } \\
\text { economic }\end{array}$ & \\
\hline 1 & Lviv & 0.591 & 0.382 & 0.466 & 0.503 & 0.267 & 0.496 & 0.613 & 0.484 \\
\hline 2 & Boryslav & 0.482 & 0.531 & 0.622 & 0.302 & 0.138 & 0.098 & 0.115 & 0.384 \\
\hline 3 & Drohobych & 0.592 & 0.391 & 0.575 & 0.274 & 0.100 & 0.388 & 0.262 & 0.427 \\
\hline 4 & Morshyn & 0.555 & 0.647 & 0.492 & 0.551 & 0.355 & 0.368 & 0.420 & 0.474 \\
\hline 5 & Novyi Rozdil & 0.650 & 0.344 & 0.651 & 0.250 & 0.144 & 0.094 & 0.135 & 0.411 \\
\hline 6 & Sambir & 0.613 & 0.475 & 0.623 & 0.254 & 0.160 & 0.163 & 0.166 & 0.421 \\
\hline 7 & Stryi & 0.617 & 0.375 & 0.483 & 0.324 & 0.182 & 0.521 & 0.252 & 0.422 \\
\hline 8 & Truskavets & 0.564 & 0.463 & 0.597 & 0.317 & 0.481 & 0.222 & 0.341 & 0.481 \\
\hline 9 & Chervonohrad & 0.543 & 0.326 & 0.399 & 0.261 & 0.118 & 0.317 & 0.280 & 0.353 \\
\hline 10 & Brodivskyi & 0.413 & 0.415 & 0.752 & 0.283 & 0.125 & 0.166 & 0.214 & 0.426 \\
\hline 11 & Buskyi & 0.493 & 0.428 & 0.689 & 0.416 & 0.498 & 0.431 & 0.128 & 0.482 \\
\hline 12 & Horodotskyi & 0.491 & 0.460 & 0.655 & 0.403 & 0.324 & 0.361 & 0.110 & 0.440 \\
\hline 13 & Drohobytskyi & 0.496 & 0.447 & 0.720 & 0.324 & 0.393 & 0.033 & 0.029 & 0.422 \\
\hline 14 & Zhydachivskyi & 0.260 & 0.420 & 0.675 & 0.367 & 0.181 & 0.066 & 0.095 & 0.350 \\
\hline 15 & Zhovkivskyi & 0.601 & 0.413 & 0.726 & 0.418 & 0.272 & 0.166 & 0.104 & 0.451 \\
\hline 16 & Zolochivskyi & 0.495 & 0.393 & 0.712 & 0.393 & 0.124 & 0.254 & 0.102 & 0.415 \\
\hline 17 & Kamyanka-Buzkyi & 0.536 & 0.520 & 0.665 & 0.470 & 0.360 & 0.297 & 0.130 & 0.458 \\
\hline 18 & Mykolaivskyi & 0.576 & 0.417 & 0.741 & 0.337 & 0.235 & 0.000 & 0.185 & 0.444 \\
\hline 19 & Mostyskyi & 0.534 & 0.399 & 0.710 & 0.348 & 0.279 & 0.000 & 0.111 & 0.417 \\
\hline 20 & Peremyshlianskyi & 0.201 & 0.480 & 0.689 & 0.367 & 0.221 & 0.000 & 0.073 & 0.344 \\
\hline 21 & Pustomytivskyi & 0.599 & 0.417 & 0.595 & 0.573 & 0.334 & 0.489 & 0.275 & 0.479 \\
\hline 22 & Radekhivskyi & 0.387 & 0.488 & 0.676 & 0.452 & 0.228 & 0.357 & 0.212 & 0.436 \\
\hline 23 & Sambirskyi & 0.518 & 0.478 & 0.709 & 0.396 & 0.251 & 0.304 & 0.045 & 0.438 \\
\hline 24 & Skolivskyi & 0.558 & 0.539 & 0.803 & 0.270 & 0.190 & 0.026 & 0.141 & 0.461 \\
\hline 25 & Sokalskyi & 0.484 & 0.458 & 0.686 & 0.216 & 0.276 & 0.000 & 0.148 & 0.412 \\
\hline 26 & Starosambirskyi & 0.484 & 0.482 & 0.772 & 0.347 & 0.296 & 0.000 & 0.139 & 0.443 \\
\hline 27 & Stryiskyi & 0.508 & 0.539 & 0.713 & 0.432 & 0.547 & 0.172 & 0.164 & 0.488 \\
\hline 28 & Turkivskyi & 0.499 & 0.545 & 0.734 & 0.281 & 0.157 & 0.000 & 0.033 & 0.403 \\
\hline 29 & Yavorivskyi & 0.689 & 0.446 & 0.775 & 0.316 & 0.243 & 0.150 & 0.146 & 0.488 \\
\hline
\end{tabular}

Note. Matrix of critical conditions of economic security:
$0-0.1918$ Danger
$0.1919-0.4833$ Threat
$0.4834-0.6755$ Risk
0.6755- 1 Security

Source: Own calculation. 
condition of threat. According to the qualitative assessment of industrial security, 26 out of 29 administrative-territorial units are in the condition of threat. The indicators of volume of manufacturing products sold, agriculture and the number of small enterprises affect the level of this component of economic security the most. The index of the component is increasing slightly, despite the decrease of indices in 11 administrative and territorial units.

Considerable variation of indices in the Lviv Oblast is characteristic of investment security. High dynamics of its index is found out. InvS index ranges from 0.100 in Drohobych to 0.547 in Stryisky raion. The cities of Chervonohrad and Drohobych are in the condition of danger, Stryiskyi and Buskyi raions - in the condition of risk, others - in the condition of threat. Overall, in the region, the indicators that characterize the ratio of investments volume to the cost of fixed assets and their depreciation positively affect the forming of the index of investment security. Security index declined slightly given the negative trends in 18 raions.

The calculated indices of innovational security (IS) for 2005, 2010 and 2015 showed its increase. A major threat to the ES in general is the presence in the region of administrative-territorial units without indexes of innovational activity, causing a significant differentiation of the index of IS in the Lviv Oblast: from 0 in six administrative and territorial units to 0.521 in Stryi (Tab. 2). The administrative and territorial units, in which over the monitoring period the index of IS dropped to zero require special attention. Particularly they are Peremyshlianskyi, Mykolaivskyi and Sokalskyi raions. 11 of administrative-territorial units are in the condition of danger, half - in the condition of threat, three - in the condition of risk.

Components of economic security in the condition of danger. Meso- and external economic security (MSS) in the Lviv Oblast among other components of ES has the lowest index value and shows negative dynamics. According to the qualitative assessment of MSS values, only Lviv is in the condition of risk, in the condition of threat -18 , in the condition of danger - 10 administrative-territorial units (Tab. 2).

\section{Integral assessment of economic security of Lviv Oblast}

The level of economic security of administrative- territorial units is identified as integral index, which reflects its quantitative and qualitative characteristics relative to other administrative-territorial units of a region. Calculation of such index primarily is the basis for comparison of ES in a region and, therefore, helps to identify its spatial differentiation. This differentiated approach enables to take action to improve, stabilize or maintain the economic situation within safe limits.

Integrated assessment of economic security and classification of the administrative-territorial units of the Lviv Oblast over the period of 2005-2010-2015 is conducted with the use of PCA. This allowed not only to identify the level of economic security of the region, but also to compare its spatial, structural and temporal features.

In order to calculate the integral index of economic security by PCA, seven indeces of relevant components were used. As a result, three factors that explain $75 \%$ of the total variance were found. The first factor, which explains $32 \%$ of the total variance, has the highest factor load which correspond to the indexes of ecological (0.87), meso- and external economic (0.86) and innovational security (0.79). The second factor explains $26 \%$ of the output information and integrates the indices of investment (0.83), industrial (0.73) and social security (0.71). The index of demographic security (0.92) forms the third factor alone.

The influence of each factor on the economic security of the administrative-territorial units in the Lviv Oblast was defined. Indices of the first factor influence on economic security in most of the cities of oblast. The second factor has a decisive influence on the level of ES in Morshyn, Pustomytivskiy and Stryiskyi raions, and the third factor - in Novyi Rozdil, Sambir and Yavorivskyi raion. Simultaneously in six of administrative-territorial units, all the three factors are very weak, since the factor weights have negative values in them. Among the components of economic security, value of integral index is mostly influenced by ecological and demographic components ( 0.205 and 0.179 respectively), and less - by social (0.087).

Over the period of 2005-2010, the level of ES in the Lviv Oblast had been growing slightly - by an average of $6 \%$. In spatial respect, only in six of the administrative-territorial units of the Lviv Oblast, the level of ES declined, more than a third of the administrative-territorial units was included in the group with minor, and ten with medium rate of increase of the integral index of economic security. In particular, the highest rates of increase in the region demonstrated Horodotskyi (31\%) and Buskyi (23\%) raions. The dynamics of the index in the next period of 2010-2015 is characterized by a decrease of indices from one to $12 \%$ in seven administrative-territorial units. The most negative changes occurred in Zhydachivskyi raion and the city of Morshyn. And in 
Sambirskyi, Starosambirskyi and Buskyi raions, the integral index increased from 16 to $20 \%$.

The quantitative values of the integral index of ES are taken as the basis of selection of two types of administrative-territorial units, which correspond to the conditions of risk and threat (Tab. 2). Among the administrative-territorial units of the region in the condition of threat, three subtypes are identified, namely: minor, medium and substantial threat. In the most of administrative-territorial units demographic and ecological components have high contribution to the integral economic security index.

The first of the selected types unites the raions of Yavorivskyi, Stryiskyi and the city of Lviv, which have rates of the integral index of economic security in the range of 0.484 to 0.488 (Fig. 3). This level of ES is reached due to relatively higher shares of meso- and external economic (Lviv) and investment (Stryiskyi raion) components. In this type of administrative-territorial units, the indeces of social and

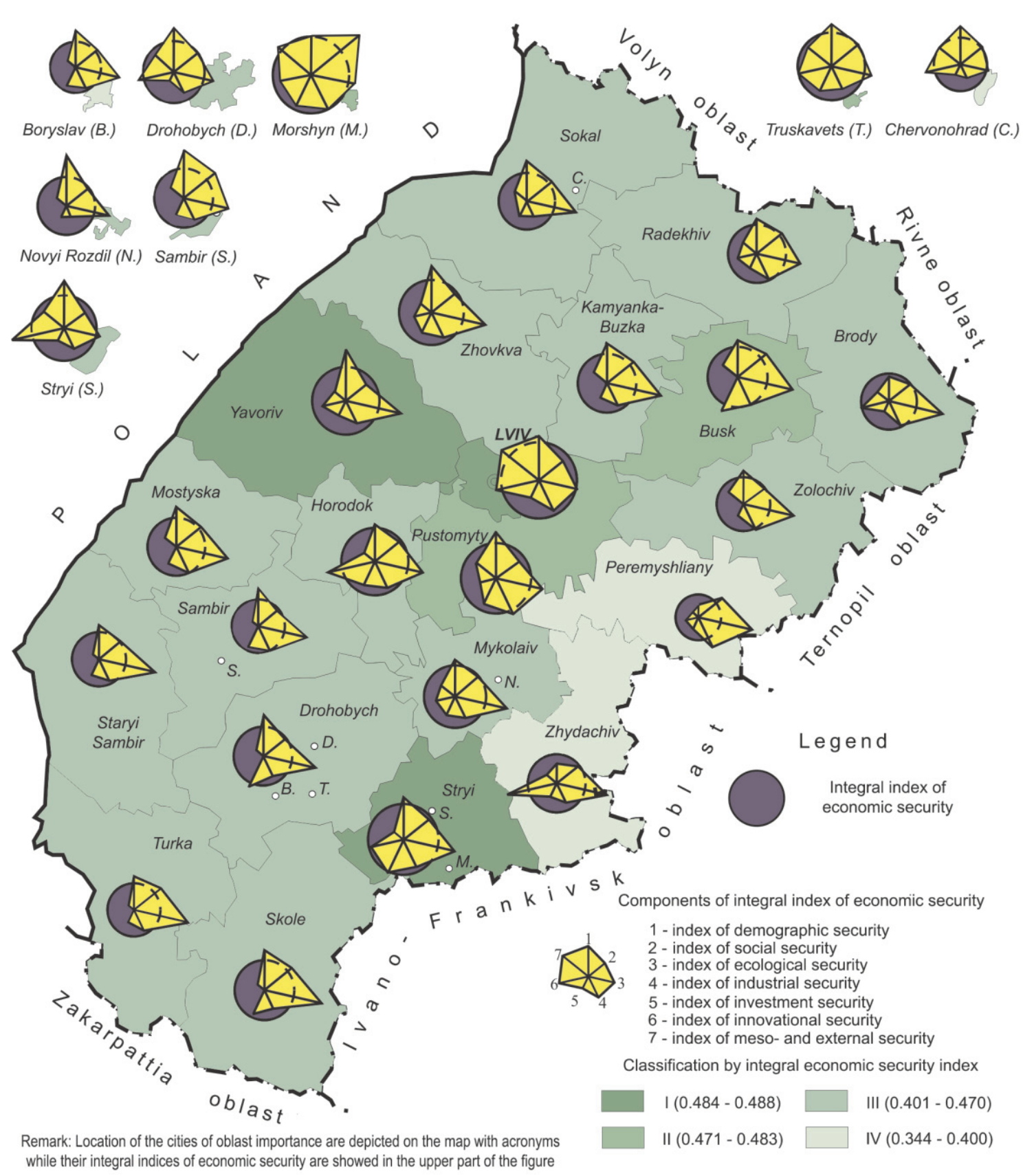

Fig. 3. Integral indices of economic security in Lviv Oblast, 2015. On the main map integral indices of respective administrative raions (NUTS-3 level) is depicted. In the upper part of the figure integral indices of city of oblast importance is showed (NUTS-3 level), which names coincides with raion's name, but in regional statistics data on them are separated. City of Lviv belongs to cities of oblast importance and showed on the main map.

Source: Own studies. 
innovational components negatively affect the economic security.

To administrative-territorial units subtype, which is characterized by minor threat of ES, belong four administrative-territorial units, including two raions and two cities. The integral index of economic security of these administrative-territorial units ranges from 0.474 in Morshyn to 0.482 in Buskyi raion. The biggest risks of ES in this subtype are relatively low indexes of investment, social and industrial components.

The subtype of medium threat of ES that unites 18 of administrative-territorial units, is formed by the three cities of oblast importance and north-eastern and southern raions of the Lviv Oblast (Fig. 3). The index of economic security in the administrativeterritorial units of this subtype ranges from 0.403 in Turkivskyi raion to 0.461 in Skolivskyi raion. Innovational, investment and meso- and external economic components have low values, in particular, in six administrative-territorial units there is absolutely no innovational activity. In this subtype ecological and social components have a slightly bigger contribution to forming of the integral index of economic security.
Four of the administrative-territorial units of the Lviv Oblast are classified to the subtype with substantial threat to ES. Rates of the economic security index in it range from 0.344 in Peremyshlianskyi raion to 0.384 in Boryslav. The values of the integral index of ES are formed in this subtype by high rates of ecological, demographic (except Peremyshlianskyi and Zhydachivskyi raions) and industrial components. Along with that, a threatening situation for ES of administrative-territorial units is created by rates of innovational (in most of administrativeterritorial units there is none at all), investment and meso- and external economic components (Fig. 3).

\section{SWOT analysis}

The results of the research of economic security in the Lviv Oblast bear witness to most of administrative-territorial units being in the conditions of threat and risk, which implies the need for urgent measures for its improvement. To do this, first of all, a strategy to guarantee ES of the Lviv Oblast must be developed, which would bring together a set of goals and measures aimed at efficient use of region potential, achievement of which will create

Tab. 3. Matrix of scenarios of economic security change of Lviv Oblast

\begin{tabular}{|c|c|c|}
\hline \multicolumn{2}{|r|}{ Favorable opportunities } & Potential threats \\
\hline \multicolumn{2}{|r|}{ Opportunity-Strength strategies } & Opportunity-Threat strategies \\
\hline & $\begin{array}{l}\text { Achievement of sustainable positive natural population growth. } \\
\text { Increase of the quality of social services. Reduction of anthropo- } \\
\text { genic impact through the use of resource-saving and low-waste } \\
\text { technologies. Improvement of food self-sufficiency. Increase of } \\
\text { the number and range of products of small enterprises. High } \\
\text { rates of goods and passenger turnover due to successful use } \\
\text { of transit potential and borderland infrastructure. Move of } \\
\text { innovative activity of enterprises to a new level through local } \\
\text { research efforts. increasing of foreign and domestic investment. } \\
\text { Implementation of export opportunities of a region }\end{array}$ & $\begin{array}{l}\text { Positive dynamics of natural growth. Growth of ter- } \\
\text { ritorial disproportions in social infrastructure. Growing } \\
\text { problem of recycling and disposal of industrial and } \\
\text { domestic waste. Stagnation of agricultural production } \\
\text { for the lack of interest and low profitability. Reduction } \\
\text { of the share of engineering and high-tech production. } \\
\text { Trade direction of small enterprises. Reduction of sci- } \\
\text { entific and technical personnel and research projects. } \\
\text { Reduction of growth of foreign direct investment }\end{array}$ \\
\hline \multicolumn{2}{|r|}{ Weakness-Opportunity strategies } & Weakness-Threat strategies \\
\hline 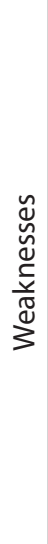 & $\begin{array}{l}\text { Reduction of the level of child mortality and labor migration } \\
\text { by conducting of corresponding reforms. Improvement of the } \\
\text { investment climate contributes to the construction of hous- } \\
\text { ing and infrastructure, including social. Upgrade of equipment } \\
\text { and technologies for recycling and purification of waste will } \\
\text { reduce the risk of industrial accidents. Attraction of investment } \\
\text { and subsidies to farmers and private households will constrain } \\
\text { negative trends in agricultural production. Diffusion of innova- } \\
\text { tions into peripheral raions and their involvement in innovative } \\
\text { activity. Estimated economic policies and successful promotion } \\
\text { will help attract investors to the region. Development of the } \\
\text { internal market will contribute to the qualitative and quantita- } \\
\text { tive growth of small enterprises }\end{array}$ & $\begin{array}{l}\text { High depopulation and population aging, growing } \\
\text { problem of child mortality. Reduction of intellectual } \\
\text { level of workforce. Aggravation of social problems due } \\
\text { to poor quality of life and spiritual level of population. } \\
\text { Absence of access to education and healthcare of } \\
\text { high quality for the majority of the population. Slight } \\
\text { demand for local products due to low competitiveness. } \\
\text { Dotation of unprofitable enterprises. Closing up of } \\
\text { small enterprises. Economic uncertainty and instability } \\
\text { of policy, excessive bureaucracy and corruption will } \\
\text { lead to withdrawal of foreign capital. Closing up of lo- } \\
\text { cal research centers, along with technology import }\end{array}$ \\
\hline
\end{tabular}

Source: Own studies. 
favorable conditions for the increase of economic security generally and its individual components in particular.

A preliminary step of the development of ES strategy is the conduction of SWOT analysis. According to the results, four scenarios of changes of ES in the Lviv Oblast are suggested, which take into account favorable opportunities and potential threats of the external environment, the strengths and weaknesses of the internal environment (Tab. 3).

The most favorable scenario is Strength-Opportunities, as it is based on the strengths of the region ES with maximum implementation of favorable opportunities of the external environment. The strength-Threat scenario is to use the strengths to prevent potential threats. According to this scenario, ES will be in a certain stagnation or have a slight but positive trend. The Weakness-Opportunity scenario involves taking into account the maximum action of favorable opportunities of external environment for improvement of weaknesses of the internal environment. The Weakness-Threat scenario is the most dangerous scenario for the development of the region. It is characterized by a combination of weaknesses of internal environment with potential threats of internal environment. According to this scenario, the region will be in the condition of danger.

\section{Conclusions}

The research dealt with the problem of ES structuring while transition from national to oblast region level study and defined the components of ES of administrative raion and cities of oblast importance: demographic, social, ecological, industrial, innovational, investment, meso- and external economic.

For the research of ES at the oblast level, indicators that most fully describe current and dynamic condition of ES in general and its components in particular are selected from the data list of regional statistics.

The authors presented the methods of integral assessment of ES, which include the following components: 1) selection of indicators of measurement of ES at the level of administrative-territorial units of oblast - raions and cities; 2) quantitative and qualitative spatial-temporal assessment of ES components of a region by formalization methods; 3 ) quantitative and qualitative spatial-temporal integral assessment of ES of a region; 4) classification of administrativeterritorial units of a region according to the ES level; 5) creation of synthetic map of geospatial organization of region $\mathrm{ES} ; 6$ ) development of future scenarios of region ES using the technique of SWOT analysis;
7) according to the results of PCA and critical conditions matrix, it is determined that in the Lviv Oblast, demographic, social, ecological components are in the condition of risk, in the condition of threat - industrial, innovational, investment, in the condition of danger - meso- and external economic. Compared with the previous time slices, demographic and social securities are characterized by significantly lower differentiation of inner-oblast indices. At the same time, innovational, investment and meso- and external economic securities are in the three out of four conditions of economic security. Spatial-temporal analysis found that in 2015 as compared to 2010, positive changes occurred only in social and industrial security; 7) qualitative interpretation of quantitative values showed that most of the administrative-territorial units of the region are in the condition of threat. In proposed by authors classification, administrative- territorial units in the condition of substantial, medium and minor threat, and also three administrative and territorial units in the condition of risk, are distinguished. The most substantial threat to the economic security of the region are low rates of investment component and innovative activity, particularly in the third of the administrativeterritorial units, there is no such activity; 8) One of the main conclusions of the research is that low level of ES in the Lviv Oblast is found, therefore in following research, it is necessary to develop a concept of economic security strategy.

\section{References}

Архів видань Головного управління статистики у Львівській області, http://www.lv.ukrstat.gov.ua/ukr/publ/archive_publ.php?ind_page=archive [20.01.2017].

База даних Головного управління статистики у Львівській області, http://database.ukrcensus.gov.ua/statbank_ Iviv/Dialog/statfile.-asp?lang=1, Головного управління статистики у Львівській області [20.01.2017].

Варналій 3., 2011, Економічна безпека України: проблеми та пріоритети змічнення, Знання України, Київ.

Герасимчук 3., 2006, Економічна безпека регіону: діагностика та механізми забезпечення, Настир'я, Луцьк.

Геєць В., 1999, Концепція економічної безпеки України, Логос, Київ.

Мунтіян В., 1999, Економічна безпека України, КВІЦ, Київ.

Наконечна Г., 2010, Економічна безпека: поняття та підходи до трактування, Науковий часопис НПу ім. М. П. Драгоманова. Серія 4. Географія і сучасність, 6(23), 17-22.

Наконечна Г., Книш М., 2011, Критерії виміру економічної безпеки, Наукові записки ТНПу. Серія: Географія, 30, 100-105.

Новікова О.Ф., Покотиленко Р.В., 2006, Економічна безпека: концептуальні визначення та механізми забез- 
печення, Ін-т економіки промисловості НАН України, Донецьк.

Пастернак-Таранушенко Г., 1994, Економічна безпека держави, Інститут державного управління і самоврядування при Кабінеті Міністрів України, Київ.

Пономаренко В., Клебанова Т., Чернова Н., 2004, Экономическая безопасность региона: анализ, оценка, прогнозирование, ИД “ИНЖЭК”, Харьков.

Сухоруков А., 2009, Система економічної безпеки держави, Стилос, Київ.

Шлемко В., Бінько І., 1997, Економічна безпека України: сутність і напрямки забезпечення, НІСД, Київ. 